\title{
A Discourse of a Different Kind: On Fabulation and Method in Goethe's Unterhaltungen deutscher Ausgewanderten
}

\author{
MichaEL SAMAN \\ Independent Scholar
}

\begin{abstract}
Man erfährt wieder bei dieser
Gelegenheit, daß eine vollständige

Erfahrung die Theorie in sich enthalten muß. Um desto sichrer sind wir, daß wir uns in einer Mitte begegnen, da wir von so vielen Seiten auf die Sache losgehen.

- Goethe to Schiller, October 14, 1797

(Goethe, Gedenkausgabe, 439)
\end{abstract}

When the journal Die Horen began to appear in 1795, the responses to Schiller's speculative aesthetic contributions and to Goethe's unorthodox Unterhaltungen deutscher Ausgewanderten were not uniformly positive. "Viele klagen über die abstrakten Materien," reported Schiller to Goethe, "viele sind auch an Ihren Unterhaltungen irre, weil sie, wie sie sich ausdrücken, noch nicht absehen können, was damit werden soll. Sie sehen, unsre deutschen Gäste verleugnen sich nicht; sie müssen immer wissen, was sie essen, wenn es ihnen recht schmecken soll. Sie müssen Begriff davon haben" (Goethe, Gedenkausgabe, 76; emphasis in original). Indeed, the Unterhaltungen have a history of perplexing their readers, and literary criticism has a history of seeking to pin down the novella's elusive Begriff. Sufficiently inscrutable on both a formal and a substantive level to resist many expectations we may bring to the text, or conventions we may expect it to operate within, the Unterhaltungen seem to compel interpreters either to conclude that they largely defy interpretation, or, alternatively, to seize upon one strand or subtext within them, and put this forth as the true meaning behind the novella's inconstant structure. In the following, I will seek to explain the thinking that underlies the shifting quality of the text, drawing first on Goethe's philo-

Monatshefte, Vol. 108, No. 4, 2016

(C) 2016 by The Board of Regents of the University of Wisconsin System 
sophical dialogue with Schiller, out of which the idea for the Unterhaltungen emerges; then tracing out the narrative treatment of central conceptual problems within the conversations of the emigrés; and, finally, exploring the way the theoretical and methodological concerns in the frame narrative relate to Goethe's ideas on science, philosophy, and history. In this way, I show how the Unterhaltungen take shape as an experimental synthesis between the rigorous empirical grounding of Goethe's scientific work and the free play of the literary imagination called for by Schillerian aesthetic theory, and how, in turn, this synthesis has ramifications in different facets of Goethe's thought. In the past, many critics have been ungenerous. As Gerhard Fricke once wrote:

Das Befremden und Kopfschütteln, mit dem in Weimar und anderswo das Bündel von Anekdoten und Geschichten aufgenommen wurde, das Goethe in den beweglichen Rahmen seiner um Unterhaltung bemühten Revolutionsflüchtlinge einfügte, ist, ob auch meist respektvoll kaschiert, bis heute ziemlich unverändert geblieben - von einigen tollkühnen Versuchen abgesehen, symbolischen Tiefsinn und paradigmatische Novellenvielfalt selbst da zu statuieren, wo ganz offenbar ein gehaltloser Stoff schlecht erzählt und geistlos erörtert wird (Fricke, 273).

Bernd Witte, meanwhile, ventured to postulate "systematisch-historische[r] Gehalt" in the novella, arguing that this cohesive aspect of the work "konnte bis heute unentdeckt bleiben weil er im Gegensatz zu Schillers hohem Pathos in scheinbar unverbindlichem Plauderton daherkommt und sich der eher zur Unterhaltungsliteratur zu zählenden Gattungen der 'gespenstermäßigen Mystifikationsgeschichte' und der moralischen 'Familiengemälde' bedient" (Witte, 462). More recently, Chenxi Tang has applied legal and political theory to find, among the stories the emigrés tell, an "exaltation of the novella" that raises the genre "to the very epitome of the poetic work of art" (Tang, 88). Somehow, it is true that-paradoxically-the Unterhaltungen are both fraught with apparent randomness and incongruity, and contructed around a distinct conceptual underpinning. Further work remains to be done in order to explain how these apparently contradictory characteristics come together within the text.

If there is literary merit to be discerned amid the contentious chit-chat and low-brow storytelling of the Unterhaltungen, or if there is a consistent concept to be discerned within the whole, the burden proves to be very much upon the reader to establish this. In fact, in a quite openly reflexive way, the novella seems at one juncture to tell us as much: "Es kommt freilich vieles auf die Beobachter an, und was für eine Seite man den Sachen abzugewinnen weiß," is the Old Man's reply when Luise protests that his tales may be without merit; "alles, was ich vorzubringen habe," he concedes, "hat keinen Wert an sich" (Goethe, Werke, vol. 6, 145). An absence of intrinsic merit, 
the Old Man asserts, needn't stop his interlocutors from construing something meaningful in the tales - at least if they know how to look at things the right way. The Baroness, for her part, takes a starkly contrasting view, insisting that stories should aspire to the "Einheit des Gedichts" (166). While arguing over the stories they tell each other, the characters in the novella seem thus to be arguing also about the very narrative-and indeed the genre-they themselves are part of. Whether we choose to view the Unterhaltungen through the eyes of the Old Man or through the ideals of the Baroness-i.e., whether we regard them as a messy textual inkblot or as a pristine poetic unity - what comes to the foreground either way is the process of judgment by which the reader goes about determining meaning or unity in them. Heather Sullivan has argued that the crux of the text is to be found in its "play with perception, interpretation, and the senses as part of our dynamic interactions with the world." This viewpoint is, I believe, entirely correct; more than that, if we press it to its fullest iteration, it can free us from distracting questions about whether the "true" meaning of the Unterhaltungen has to do with politics, or aesthetics, or science, or philosophy, etc. Following Sullivan's foregrounding of perception, we are able to answer that the novella is ultimately about none and all of these fields: none, because it deals with fundamental epistemological questions that cannot be constrained to any single area of inquiry; and all, because, of course, all areas of serious methodical inquiry are predicated upon certain principles and practices of observation and judgment. As Sullivan claims, "Goethe concentrates on a grounded interaction with our surroundings that might shift our understanding of everything" (152; emphasis in original). Gerhard Neumann has characterized Goethe's work around 1800 as forming part of a broader "Umordnung von Wissensstrukturen" and a "Polyfokalisierung der Wahrnehmung" characteristic of the post-Enlightenment era. Well beyond the specific scope of literature, Goethe's work participates in a sweeping epistemological shift marked by a "lebhafte[r] mehrseitige[r] Transfer zwischen Naturwissenschaften, Geschichte [und] Philosophie" and distinguished, in Goethe's work in particular, by a "Neubestimmung des Verhältnisses von Einzelnem und Ganzem durch die neuen Leitbegriffe des Aperçus und des Symbols" (Neumann, 472; emphasis in original). In line with this profound rethinking of the structure of knowledge itself, the main narrative of the Unterhaltungen is organized to a great extent around the very question Neumann specifies: the relation of the particular to the universal, of the empirical to the ideal. ${ }^{1}$ The theorization of these issues can be followed, Neumann observes, not only in Goethe's literary and scientific writings, but also in his epistolary exchange with Schiller. "Das Briefgespräch zwischen Schiller und Goethe kreiste immer wieder um die eine Schwierigkeit, wie im einzelnen Faktum, im augenblicklichen Erlebnis die Idee des Ganzen, ein allgemeiner Sinn zu fassen und zu halten sei, wie das individuell Erfahrene sich mit dem generellen Sinn vermitteln lasse" (498; 
emphasis in original). In order to appreciate the philosophical stakes of the Unterhaltungen, we must then begin with this dialogue, in which the novella was conceived.

\section{II}

The mutual intellectual push and pull that marked Goethe's incipient collaboration with Schiller forms not only the backdrop, but indeed much of the very substance of the Unterhaltungen. ${ }^{2}$ In 1794, Schiller had conceived of a new literary journal, Die Horen, to serve the aesthetic cultivation of the German intelligentsia and broader reading public, and began actively wooing Goethe as co-editor and contributor. Wilhelm Meisters Lehrjahre had just been completed, and Goethe and Schiller both initially thought this novel would be well suited for serialization in the first issues of the journal; however, it had already been promised to a different publisher, leaving Goethe and Schiller to brainstorm ideas for a brand new piece for Goethe to write. Having recently completed a major novel, however, Goethe was quite eager to get away, at least for the time being, from the strenuous demands of such ambitious and complex writing: "Zu kleinen Erzählungen habe ich große Lust," he writes to Schiller, "nach der Last, die einem so ein Pseudo-Epos, als der Roman ist, auflegt" (Goethe, Gedenkausgabe, 40). This being the case, the prospect of starting a work from scratch came to be not merely a necessary evil, but actually a desirable circumstance that allowed Goethe to proceed with greater levity and freedom, and, at the same time, to remain open to Schiller's ongoing input as both intellectual confidant and editor. "His enthusiasm for the new project was boundless," writes Nicholas Boyle, and Goethe "overflowed with suggestions: a series of verse epistles for the opening issues, a retelling of stories from Boccaccio's French imitators, a correspondence with Schiller on aesthetics that could begin straight away and be printed as it grew" (Boyle, 228). The Episteln did come to be written, and were published in the first two issues. At Schillers encouragement, Goethe also developed two tales by François de Bassompierre into the "schöne Krämerin" and the "Geschichte vom Schleier" that appear in the Unterhaltungen. The model of Boccaccio's Decameron, in which the telling of stories serves to pass the time and to offer needed diversion during the Plague, is central in the Unterhaltungen, which is constructed around a parallel between the Plague in Boccaccio's Italy and the political instability of 1790s Germany. The idea of a dialogue with Schiller on aesthetics, moreover, to be published "as it grew," came likewise to be realized-though not explicitly-by incorporation into the fabric of the Unterhaltungen themselves.

In a manner Schiller probably would not have expected, Goethe-who was so frank about his willingness to explore whatever sort of material Schiller felt would be effective for the aims of Die Horen-did indeed take the 
opportunity to set Schillerian ideas into play, and thereby in effect to conduct a literary experiment as to the possibility of a literary synthesis of their respective paradigms of thought. Schiller's and Goethe's broad aims in terms of the kind of cultural politics that the times called for were largely compatible, yet key aspects of their philosophical principles were deeply at oddsa fact that created a productive tension between them, and that, one may surmise, made all the more intriguing for Goethe the idea of constructing what critics have identified as his "Gegenentwurf," his "epische[-] Kontrafaktur," his "fabulierende[s] Nachzeichnen" of Schiller's letters Über die ästhetische Erziehung des Menschen, which were serialized in Die Horen simultaneously with the Unterhaltungen (Gaier, 211; Pfaff, 321; Mommsen, 504). The observation that Goethe was in a certain sense rewriting Schiller's ideas runs the risk of being rather oversimplified, however, for the significant differences that inhere between narrative fiction and theoretical aesthetics in general, and between Goethe's keen empiricism and Schiller's speculative thought in particular, yield conceptual disjunctions that demand considerable creativity on the part of the author in order to bridge them in a narrative work. Perhaps inevitably, the result of this process is some rather unconventional storytelling. Serialized in Die Horen while they were still in the process of being written, the Unterhaltungen reflect the fact that Goethe had the possibility to adjust the structure and material of the text as he went along, gradually reorienting the overall trajectory of the narrative, responding to new events and ideas, and even constructing in this process a dialogue with other pieces appearing in Die Horen. Due to this manner of being published piece by piece and being thought through progressively as it appeared, the work must be seen as developing very much in real time - a fact that contrasts markedly with most of Goethe's Weimar-era output. Unlike earlier works of the Sturm und Drang period, for example, the relatively spontaneous composition of which, with little revision afterward, was typical of the aesthetics and temperament of the time, Goethe's more canonical work of the Weimar period tended to be the product of careful reflection, and often the accumulation of many years of work. The resulting contrast with a book such as Wilhelm Meister, which appeared around the same time, is what has helped earn the Unterhaltungen their reputation as something of a "Kuckucksei" within Goethe's literary oeuvre (Gaier, 225). The fact that they reflect an exploratory philosophical dialogue with a new interlocutor also contributes to their eclectic aesthetic.

In contrast to the much more orthodoxly Kantian Schiller, Goethe categorically rejected the desirability or even the possibility of abstracting ideas into a speculative realm where they would be separated from the real. Such a separation, however, was a central tenet of Schiller's thought, and Goethe remained skeptical of the transcendental philosophical apparatus that Schiller applied to his political and aesthetic thinking. Both Schiller and Goethe were 
very cognizant of this difference; as Schiller writes to Goethe at the outset of their correspondence:

Mir fehlte das Objekt, der Körper zu mehreren spekulativischen Ideen, und Sie brachten mich auf die Spur davon. Ihr beobachtender Blick, der so still und rein auf den Dingen ruht, setzt Sie nie in Gefahr, auf den Abweg zu geraten, in den sowohl die Spekulation als die willkürliche und bloß sich selbst gehorchende Einbildungskraft sich so leicht verirrt. [... ] Beim ersten Anblicke zwar scheint es, als könnte es keine größere Opposita geben, als den spekulativen Geist, der von der Einheit, und den intuitiven, der von der Mannigfaltigkeit ausgeht. Sucht aber der erste mit keuschem und treuem Sinn die Erfahrung, and sucht der letzte mit selbsttätiger freier Denkkraft das Gesetz, so kann es gar nicht fehlen, daß nicht beide einander auf halbem Wege begegnen werden (Goethe, Gedenkausgabe, 13 and 15).

Goethe, for his part, was likewise eager for Schiller's input towards increasing the purview and precision of his Denkkraft, and therefore readily accepted the invitation to let their minds meet halfway, even though —or perhaps precisely because-as Goethe concedes, "[i]ch komme mir gar wunderlich vor, wenn ich theoretisieren soll" (30). An experiment in synthesizing "Opposita" is thus the basic project at hand.

Meanwhile, the French Revolution and its aftermath-in this case, the War of the First Coalition - were what lent these matters more than just theoretical urgency, and the question of how to engage with this historical exigency becomes a testing ground for their ideas. Schiller's response to developments in France had gone through more marked changes than had Goethe's: Schiller initially supported the revolution on the basis of its ideals, but, increasingly taken aback by its violent repercussions, renounced this support and began to conceive literary projects intended to help bring about a more humane society, free of such brutality. As is made clear in the "Ankündigung" for Die Horen, the journal was expressly conceived toward this end. The "Ankündigung" is worth closer consideration because it not only formulates in nuce the general system of idealistic aesthetics to which Goethe would so directly be responding as he composed the Unterhaltungen, but it also states the specific expectations for the contributions being sought for the journalexpectations that Goethe, with an inimitable mix of irony and sincerity, would transpose, with a twist, into fictional form. Schiller writes:

Je mehr die allgemeine Aufmerksamkeit durch die lebhafteste Teilnahme an den politischen Begebenheiten des Tages und den Kampf entgegengesetzter Meinungen und Parteien jetzt auf die Gegenwart gerichtet ist, desto dringender wird das Bedürfnis, die dadurch eingeengten Gemüter durch ein allgemeineres und höheres Interesse an allem, was rein, menschlich und über den Einfluß der Zeiten erhaben ist, wiederum in Freiheit zu setzen und dem durch den Anblick der Zeitbegebenheiten ermüdeten Leser eine fröhliche Zerstreuung zu verschaffen (Schiller, 110). 
While it is clear why Goethe will have been receptive to the idea of a literary remedy to the political crises of the day, we can, at the same time, clearly see manifestations in this passage of the separation that Goethe questioned between the transcendental subject matter of the intellect and the concrete manifold of experience. Unlike Goethe's thought, Schiller's is predicated upon there being something "rein, menschlich und über den Einfluß der Zeiten erhaben" that can be written on in lieu of the actual political vicissitudes of the here and now. Schiller thus proposes, in effect, a discursive retreat into a 'purely' aesthetic discursive space that stands in opposition to the "Begebenheiten des Tages." This becomes more explicit as the "Ankündigung" continues:

Sich alle Beziehung auf den jetzigen Weltlauf und die nächsten Erwartungen der Menschheit verbietend, wird [die Zeitung] mit Hilfe der Geschichte und Philosophie zu dem Ideale veredelter Menschheit die einzelnen Züge sammeln und an dem stillen Bau besserer Begriffe, reinerer Grundsätze und edlerer Sitten nach Vermögen geschäftig sein (110; emphases in original).

With the realms of the political and the aesthetic set into opposition such that the writings in Die Horen should constitute, as Schiller writes, "Unterhaltung von ganz entgegengesetzter Art" vis-à-vis the otherwise ubiquitous "Staatskritik" of the day (106), he is, paradoxically, soliciting texts that will somehow seek to ameliorate the crisis precisely by not addressing it. Goethe goes along with the ultimate intention of this project - the aim of offering edification and diversion in a time of "allgemeiner Verwirrung und Not" (Goethe, Werke, vol. 6, 128) — but he perceives an absurdity in the way Schiller models his approach. One must not, on Goethe's view, seek to abstract and refine one's discourse until it loses contact with its actual subject matter; rather, literary discourse must bring forth the complexity of things. Therefore, while Goethe by and large adheres to Schiller's requests and directives, he composes most of his narrative in a most down-to-earth and concrete manner that resists any manner of rarefied abstraction, thereby producing, ultimately, an "Unterhaltung von ganz entgegengesetzter Art" to that which Schiller had actually intended.

\section{III}

"Gegensätze," indeed, are what provide the first thrust of the work's framing narrative, with the idea of telling tales being a direct result of the confrontation between the sympathizer of the revolution, Karl, and the sympathizer of the ancien régime, the Privy Councillor-a pair of opposing temperaments and intellects that represent the incommensurability between passionate idealism (personified by Karl) and unbudging clinging to certainty and experience (personified by the Privy Councillor). "[Karl] hatte sich [...] von der blen- 
denden Schönheit verführen lassen, die unter dem Namen Freiheit sich erst heimlich, dann öffentlich so viele Anbeter zu verschaffen wußte und, so übel sie auch die einen behandelte, von den andern mit großer Lebhaftigkeit verehrt wurde" (127). The characterization of Karl focuses not only on his intense fixation on an ideal, but also on the concomitant devaluation in his worldview of any actually existing, concrete quantities: "Stand, Glücksgüter, alle Verhältnisse scheinen in Nichts zu verschwinden, indem das gewünschte Gut zu Einem, zu Allem wird" (127). The Privy Councillor remarks, "mit einiger Bitterkeit," that Karl is exemplary of those "junge Leute, die einen Gegenstand zu idealisieren geneigt seien" (133). The Privy Councillor, by contrast, is characterized as being "genau im Reden und Handeln," as holding rigidly to principle, and as both commanding confidence in others and demanding reliability from them (129). To the Baroness, he is, "so wunderlich er auch in manchen Stücken sein mag, doch ein trefflicher, rechtschaffener Mann [...] [der] ein unerschöpfliches Archiv von Menschen- und Weltkenntnissen, von Begebenheiten und Verhältnissen mit sich führt, die er auf eine leichte, glückliche und angenehme Weise mitzuteilen versteht" (135). To his antipode Karl, though, he is - for the same reasons - a caricature of "diejenigen [...], welche nur nach alten Formen denken könnten und, was dahinein nicht passe, notwendig verwerfen müßten." The confrontation between them thus exemplifies the respective perils of a mode of thinking that locates its 'one and all' purely in the ideal, and of one that, by stubborn refusal of speculation, reduces itself to being merely and unimaginatively 'archival.' Between individuals of these mindsets, as we are shown, genuine conversation simply is not possible, but rather only a gladiatorial "Hin- und Widerreden." Accordingly, the conversation between them becomes "immer heftiger, und es kam von beiden Seiten alles zur Sprache, was im Laufe dieser Jahre so manche gute Gesellschaft entzweit hatte." The Privy Councillor even escalates his contempt for people of Karl's persuasions to the point of expressing his wish, "sie alle gehangen zu sehen." Karl likewise escalates the force of his words until he avows "daß er den französischen Waffen alles Glück wünsche," and, as soon as the Revolution should take hold in Germany, "daß die Guillotine auch in Deutschland eine gesegnete Ernte finden und kein schuldiges Haupt verfehlen werde" (133). The bitter "Kampf entgegengestzter Meinungen und Parteien" Schiller spoke of is thus vividly exemplified here.

The Unterhaltungen consequently present the "traurigen Augenblicke des Loslösens und Scheidens" that accompany the departure of the Privy Councillor and his wife from the group as the inevitable consequence of failing to reconcile extremes. Up to this point, the Baroness remarks, the untempered "Gemüter" of her fellow travellers have seemed "so blind und unaufhaltsam [zu] wirken und drein[zu]schlagen wie die Weltbegebenheiten, ein Gewitter oder ein ander Naturphänomen"; moderation and reflection have hitherto fallen short (135). Moved by her sadness at her friends' parting to 
address the destructiveness of such one-sided adherence to one's own ideas and inclinations, the Baroness reminds her companions "wieviel wir sonst schon, ehe alle diese Sachen zur Sprache kamen, um gesellig zu sein, von unsern Eigenschaften aufopfern mußten, und daß jeder, solange die Welt stehen wird, um gesellig zu sein, wenigstens äußerlich sich wird beherrschen müssen" (137). The Baroness's exhortations represent a version of Goethe's notion of Entsagung, each individual being called upon to temper his or her expectations with respect to the exigencies of the situation: "Bietet alle eure Kräfte auf, lehrreich, nützlich und besonders gesellig zu sein!" (139). As the subsequent discussions show, the idea will be for the idealist concretely to substantiate the ideal he wishes to represent, and likewise for the empirical 'archivist' to venture systematically to reflect upon and to extrapolate from his experience. This new imperative-aiming to move human conduct past the unpredictability of Weltbegebenheiten and Naturphänomene-provides the thrust for the remainder of the novella.

The ethos of Geselligkeit through Entsagung finds the wholehearted approval of the Old Man:

Jeder Mensch kann ohne die mindeste Rückkehr auf sich selbst an allem, was neu ist, lebhaften Anteil nehmen; ja, da eine Folge von Neuigkeiten immer von einem Gegenstande zum andern fortreißt, so kann der großen Menschenmasse nichts willkommner sein als ein solcher Anlaß zu ewiger Zerstreuung und eine solche Gelegenheit, Tücke und Schadenfreude auf eine bequeme und immer sich erneuernde Weise auszulassen.

These comments, however, are greeted by the immediate objections of Luise, who questions the universalizing leap that he so casually seems to be making: "[...] sonst ging es über einzelne Personen her, jetzt soll es das ganze menschliche Geschlecht entgelten," she protests (141). At the outset of the novella, it had been noted how highly individualized and pronounced- "charakteristisch" and "auffallend"- the personalities of the emigrés were, their temperamental differences being amplified all the more by the precarious political circumstances (125). The Old Man's wish for them now to harmonize as a "groß[e] Menschenmasse" seems therefore to demand much too rapid a leap from stark individuality to undifferentiated collectivity. Luise is equally disapproving when the Old Man speaks of the "Sammlung" of stories he proposes to tell: "Gewiß nichts weiter als eine skandalöse Chronik" (142), she surmises, assuming that too simple a story-i.e., one lacking in added ideal value-must surely be morally debased. Luise thus objects as much to exaggerated claims of a given narrative's universal applicability as she does to the telling of a one-dimensional narrative with no resonance beyond its literal content. So the problem at issue in this key dialogue in the Unterhaltungen is that of balancing the respective symbolic values of the universal and the particular into an intelligible and also morally relevant narrative syn- 
thesis. This is the same question of speculation versus experience as in the preceding Karl/Privy Councillor episode, or, of course, in the Goethe/Schiller philosophical contrast that underlies all of this, but this time it is mediated through a consensus-seeking ethos of dialogue rather than opposition. "Ich sehe wohl, wo Sie hinauswollen," says the Baroness to the Old Man, but is sure to admonish him: "machen Sie es aber auch ihr [Luise] begreiflich" (144). On the literal level, all of this is presented by Goethe as constituting so much banal chatter over the possible indecency of the Old Man's stories, but the tenor of the narration and dialogue is deceptive. What Goethe is testing is the potential of literary narrative to bridge the gap between experience and ideas - a question with much greater ramifications than just the sensibilities of the fictional Luise.

\section{IV}

The convention, which I follow here, is to refer to the Unterhaltungen as a "novella," though this designation is in some ways problematic, as the text is composed of too many discrete parts (the main narrative, plus the seven tales the characters tell) to be considered a single, unified work. A designation that avoids this problem is "Novellenzyklus," yet this too strongly foregrounds the tales told by the characters, and thereby casts the central narrative as only a device to string them together. This, too, is an inadequate characterization. The tales told by the emigrés are, to borrow a phrase from the Baroness, something more like "Parallelgeschichten" that experimentally allow the ideas of the main narrative to resonate more widely through depiction in varying contexts. "Eine deutet auf die andere hin," says the Baroness, "und erklärt ihren Sinn besser als viele trockene Worte" (187). These tales, though, always lead back to the main narrative, and function to a certain extent as attempts to carry out the ideal of Geselligkeit to which the Baroness has challenged the group - the success or failure of each attempt becoming renewed material for discussion, thereby serving to sustain the ongoing conversation that forms the main narrative. This structure consistently focuses our attention not so much on the content of each tale told, as back onto the debate among the emigrés concerning the plausibility and value of each story. Witte has argued that the Unterhaltungen can be seen as "eine Versuchsanordnung [...], mit der die Ohnmacht der bisher üblichen Literatur angesichts der gesellschaftlich-politischen Umbruchsituation dem literarischen Fachmann vor Augen geführt werden sollte" (Witte, 472). The sequence of the narrative "experiments" the emigrés present—each successive tale standing as a Versuch for the group collectively to assess before proceeding to the next-takes on a character more formally consistent, in certain respects, with a process of scientific experimentation than with any obvious literary model. One interpretive approach to the Unterhaltungen, which Tang has taken, is 
to focus primarily on the seven stories, finding within their progression Goethe's "aesthetic remedy" to political crisis (Tang, 79). An alternative, and, I think, complementary approach — which I follow here-is to train attention on the main narrative and the "explicit focus" it brings to "questions of perception once the revolutionary background has been established and the stories have begun" (Sullivan, 156).

The tale of the singer Antonelli is introduced as "eine Geschichte, die großes Aufsehen erregte und worüber die Urteile sehr verschieden waren" (Goethe, Werke, vol. 6, 146) —and indeed, differences in judgment are exactly what it elicits. Once it has been told, the emigrés begin "ihre Gedanken und Zweifel über diese Geschichte zu äußern, ob sie wahr sei, ob sie auch wahr sein könne" (156). Next, Fritz's tale of the "Klopfgeist" is introduced as "gleichfalls eine Geschichte [...], die zwar der vorigen an Interesse nicht gleiche, aber doch auch von der Art sei, daß man sie niemals mit völliger Gewißheit habe erklären können" (157). Upon hearing Fritz's story, the Old Man expresses his regret that determining the true nature of events is not easier:

"Wenn es nur nicht überhaupt so schwer wäre zu untersuchen," sagte der Alte, "und in dem Augenblicke, wo etwas dergleichen begegnet, die Punkte und Momente alle gegenwärtig zu haben, worauf es eigentlich ankommt, damit man nichts entwischen lasse, worin Betrug und Irrtum sich verstecken könne. Vermag man denn einem Taschenspieler so leicht auf die Sprünge zu kommen, von dem wir doch wissen, daß er uns zum besten hat?" (159). ${ }^{3}$

Karl-likewise acknowledging the difficulty, or perhaps even impossibility, of reliably ascertaining states of affairs-asserts that any attempt to explain a phenomenon through a broader explanatory scheme must necessarily lead to error.

"Überhaupt," sagte Karl, "scheint mir, daß jedes Phänomen so wie jedes Faktum an sich eigentlich das Interessante sei. Wer es erklärt oder mit andern Begebenheiten zusammenhängt, macht sich gewöhnlich eigentlich nur einen Spaß und hat uns zum besten, wie zum Beispiel der Naturforscher und Historienschreiber. Aber eine einzelne Handlung oder Begebenheit ist interessant, nicht weil sie erklärbar oder wahrscheinlich, sondern weil sie wahr ist" (161).

With this foregrounding of our faculty of judgment, and these cautions regarding possible inductive error, one senses the concerns of the author who has engaged since his return from Italy with the writings of Kant, and has begun directing a major part of his scientific efforts toward demonstrating the error he perceives in Newton's system. ${ }^{4}$ The Baroness had, in her earlier rebuke to her fellow travellers, cited Naturphänomene and Weltbegebenheiten as paradigms of apparent arbitrariness and unpredictability; here, in a similar way, Karl points to the interpreters of nature and history as exemplars of systematic judgmental error. While any single discrete fact is already difficult 
to observe with true accuracy, ${ }^{5}$ any connections drawn between different observations will entail a yet greater order of complexity, and therefore a greater level of uncertainty. Explanatory theories, Goethe skeptically suggests, may ultimately reflect the judgment of an individual theorist more than they do the reality itself that they seek to explain. On the surface, there seems at this point in the Unterhaltungen to be little at stake beyond the plausibility of an extemporaneously told ghost story; to clarify the deeper epistemological stakes behind the conversation, then, the framework of the novella will now shift once again.

The problem of explaining unlikely events is given an all new immediacy when the emigrés are startled by "ein sehr starker Knall," which turns out to be caused by the mysterious, and apparently spontaneous, breaking of a nearby desk. With this occurrence, the task of accounting for the uncanny is brought out of the realm of mere Unterhaltung, and into their own immediate situation. The cause of the loud noise is immediately explained once Fritz shines light on the desk: "Die gewölbte Decke desselben was quer völlig durchgerissen; man hatte also die Ursache des Klanges." The emigrés are mystified, though, as to why the desk, built by one of Germany's most reputable artisans, should have cracked at all: "dieser Schreibtisch von Röntgens bester Arbeit" had long been regarded "als Muster einer vortrefflichen und dauerhafter Tischlerarbeit, [...] und nun sollte er auf einmal reißen, ohne daß in der Luft die mindeste Veränderung zu spüren war" (159). The barometer and the thermometer showed no readings that would explain the event, and the hygrometer they would need in order to measure the air's moisture was not at hand. "'Es scheint' sagte der Alte, 'daß uns immer die nötigsten Instrumente abgehen, wenn wir Versuche auf Geister anstellen wollen"” (160). Referring, of course, to the ghost stories previously told, the Old Man means, on the face of it, that scientific instruments cannot suffice to explain the paranormal, yet at this point in the novella, ghost stories are actually no longer the matter at hand. Rather, what is being tested are the intellects- the Geister - of the emigrés, who are now compelled to grapple with a real event that-unlike a ghost story - cannot be written off on the basis of apparent implausibility. With an entirely concrete experience before them, they now find themselves with no devices other than their minds and their senses to get from the observed fact to some manner of explanation. With this event, then, the different levels of the narrative begin to collapse into one another such that all of the discussions regarding the evaluation of narrative suddenly apply directly to reality as well. Is the seemingly spontaneous breaking of the desk in essence any different from the mysterious knocking in the "Klopfgeist" story? Is it possible to find a real reason? How do we test our explanations? How much do we trust others', or even our own, explanations? As the characters now begin debating the plausibility of what they see with their own eyes, what began as social chatter over moral ways to pass the time develops 
by the end of the novella into the question of a hermeneutics of the actual concrete present. At this juncture, we arrive at the core problem and provocation that Goethe presents: phenomena in and of themselves are ultimately unknowable to us, and narratives through which we attempt to explain them to ourselves are tentative and hypothetical constructions of which we must always remain suspicious. Is Karl right, Goethe seems to be asking - do our ideas have a true connection with the intrinsic nature of things, or are they just an Unterhaltung of sorts, a conceptual illusion that placates us in the face of the overwhelming incongruity of experience?

Fritz, undaunted, offers a theory for the Röntgen desk's breaking thatmuch like the earlier ghost stories-tests the line between the plausible and the fantastic:

Ihr wißt, daß unsre Mutter schon vor mehreren Jahren einen ähnlichen, ja man möchte sagen, einen gleichen Schreibtisch an unsre Tante geschenkt hat. Beide waren zu Einer Zeit aus Einem Holze mit der größten Sorgfalt von Einem Meister verfertigt, beide haben sich bisher trefflich gehalten, und ich wollte wetten, daß in diesem Augenblicke mit dem Lusthause unsrer Tante der zweite Schreibtisch verbrennt und daß sein Zwillingsbruder auch davon leidet. Ich will mich morgen selbst aufmachen und dieses seltsame Faktum so gut als möglich zu berichtigen suchen (160-161).

And indeed, the next day Fritz ascertains that, in a fire, the aunt's twin Röntgen desk had also cracked. Moreover, a clock that had stood upon it was found standing still, displaying the time 11:30—exactly the time the evening before when the emigrés had heard the other desk break. "Wir haben also, wenigstens was die Zeit betrifft, eine völlige Übereinstimmung," Fritz notes (208). This forms a test, then, of Karl's skeptical view of things. Is the isolated fact of the one desk breaking indeed the only matter of interest? Is a hypothetical causal connection with the breaking of the other desk something that should be seriously entertained? Or is such speculation merely "ein Spaß"? True to the Old Man's earlier remark, this seems to depend altogether on the observer:

Die Baronesse lächelte, der Hofmeister behauptete, daß, wenn zwei Dinge zusammenträfen, man deswegen noch nicht auf ihren Zusammenhang schließen könne. Luisen gefiel es dagegen, diese beiden Vorfälle zu verknüpfen, besonders da sie von dem Wohlbefinden ihres Bräutigams Nachricht erhalten hatte, und man ließ der Einbildungskraft abermals vollkommen freien Lauf (208).

While Karl's earnest attempt at scientifically sound inquiry does its best to grapple with empirical events, the mysterious event gives the disparate temperaments of the emigrés room to freely assert themselves once again, and, far from a consensus brought about by reason, it is the imagination that begins to gain the upper hand. Yet the imagination- "die willkürliche und bloß sich selbst gehorchende Einbildungskraft," in Schiller's words-is what was sup- 
posed to be tempered by connection to the concrete, while the wish for certainty was supposed to be leavened by greater speculative curiosity. Rather than moving toward a higher synthesis, then, the mindsets represented in the main narrative seem so far only to remain stubbornly disparate and conflicted, giving rise to an awkwardly halting narrative. Reading the Unterhaltungen upon their publication, Christian Gottfried Körner regretfully remarked that Goethe's writing seemed to be going "decrescendo" (quoted in Goethe, Sämtliche Werke, 1524), and in the unapologetic formal disunity and conceptual instability that mark the main narrative, one can see the reason for his discontent. Instead of synthesizing toward an ever more crystallized narrative structure, the elements of Goethe's storytelling so far seem analytically to be coming apart. The thinking behind this counterintuitive development may best be explained, I will argue, in connection with the scientific principles that Goethe is in the process of refining at this time.

\section{V}

Instinctively, Goethe writes, when we encounter phenomena, we tend-like the emigrés-first to assess them in relation to our individual interests; the untrained observer, not yet aspiring to objectivity, will judge things first and foremost in terms of whether "sie ihm gefallen oder mißfallen, ob sie ihn anziehen oder abstoßen, ob sie ihm nutzen oder schaden." Upon attaining a higher and more selfless perspective, though, the individual is able to bracket out subjective inclinations, and begins to judge phenomena less in relation to one's own interests, and instead "aus dem Kreise der Dinge [...] die er beobachtet" (Goethe, Werke, vol. 13, 10). The hazard, though, is that as we move from the initial unreflected mode of judgment to a higher level of observation, we necessarily form concepts to explain what we see, and, ironically, the conceptual apparatus that we thus construct risks eclipsing our perception of the very phenomena they were meant to explain. As Goethe writes in a 1792 essay on what he calls "die Kautelen des Beobachters" (Goethe, Gedenkausgabe, 598):

Der Mensch erfreut sich nämlich mehr an der Vorstellung als an der Sache, oder wir müssen vielmehr sagen: der Mensch erfreut sich nur einer Sache, insofern er sich dieselbe vorstellt, sie muß in seine Sinnesart passen, und er mag seine Vorstellungsart noch so hoch über die gemeine erheben, noch so sehr reinigen, so bleibt sie doch gewöhnlich nur eine Vorstellungsart; das heißt ein Versuch, viele Gegenstände in ein gewisses faßliches Verhältnis zu bringen, das sie, streng genommen, untereinander nicht haben, daher die Neigung zu Hypothesen, zu Theorien, Terminologien und Systemen, die wir nicht mißbilligen können, weil sie aus der Organisation unsers Wesens notwendig entspringen müssen (Goethe, Werke, vol. 13, 15-16). 
Later renamed "Der Versuch als Vermittler von Objekt und Subjekt," this essay centers around the possible pitfalls of perception, and presents a set of preparatory methodological cautions-Kautelen, in Goethe's parlance-for the scientific observer. The point Goethe makes is that some of the most formidable obstructions to our understanding of the world inhere not only in the intrinsic complexity of the world itself, but also in the eye-or in the mind - of the observer. "Der Versuch" therefore intends to alert the scientist to the "inner enemies" that may obtrude between him or her and the object of observation.

Man kann sich daher nicht genug in acht nehmen, daß man aus Versuchen nicht zu geschwind folgere, daß man aus Versuchen nicht unmittelbar etwas beweisen, noch irgendeine Theorie durch Versuche bestätigen wolle; denn hier an diesem Passe, beim Übergang von der Erfahrung zum Urteil, von der Erkenntnis zur Anwendung ist es, wo dem Menschen alle seine inneren Feinde auflauern, Einbildungskraft, die ihn schon da mit ihren Fittichen in die Höhe hebt, wenn er noch immer den Erdboden zu berühren glaubt, Ungeduld, Vorschnelligkeit, Selbstzufriedenheit, Steifheit, Gedankenform, vorgefaßte Meinung, Bequemlichkeit, Leichtsinn, Veränderlichkeit, und wie die ganze Schar mit ihrem Gefolge heißen mag, alle liegen hier im Hinterhalte und überwältigen unversehens den handelnden, so auch den stillen, von allen Leidenschaften gesichert scheinenden Beobachter (14-15).

The problem of how to venture from the particular to the general while still maintaining the "grounded interaction with our surroundings" that anchors Goethe's thought (Sullivan, 152) is neatly articulated here, as is the catalogue of tendencies, attitudes, and errors - many personified by various of the emigrés - that may blur judgment and obscure truth. Indeed, the above passage can easily be read as a more detailed articulation of the same complexities of judgment represented by the characters, their stories, and the connecting discussions in the Unterhaltungen. But beyond explaining the conceptual concerns that form much of the dialogue in the novella, Goethe's principles of scientific practice can be shown even to directly inform the narrative form the novella takes.

Just as aesthetic and scientific judgment operate at different levels of objectivity and detachment, Goethe argues in "Der Versuch als Vermittler" that the production of artistic and scientific texts proceeds in distinct ways, differing, for example, in the manner in which they are most effectively presented to their readership.

Denn ein Künstler tut wohl, sein Kunstwerk nicht öffentlich sehen zu lassen, bis er es vollendet hat, weil nicht leicht jemand raten noch Beistand tun kann; ist es hingegen vollendet, so hat er alsdenn den Tadel oder das Lob zu überlegen und zu beherzigen, solches mit seiner Erfahrung zu vereinigen und sich dadurch zu einem neuen Werke auszubilden und vorzubereiten. In wissenschaftlichen 
Dingen hingegen ist es schon nützlich, jede einzelne Erfahrung, ja Vermutung öffentlich mitzuteilen, ja es ist höchst rätlich, ein wissenschaftliches Gebäude nicht eher aufzuführen, bis der Plan dazu und die Materialien allgemein bekannt, beurteilt und ausgewählt sind (13-14).

This characterization of artistic versus scientific work compellingly matches the distinction between, say, the Lehrjahre and the Unterhaltungen: The former was published only when the years-long work of conceptualization and composition had been completed. The latter, by contrast, openly displays its inconsistencies and unresolved questions; it was published, piece by piece, as a work in progress, leaving the joints and sutures between its segments still palpable; and, with its many conflicting narrative voices, it is collective in composition, and is decidedly polyfocal in perspective rather than presenting a unified authorial voice. Viewed in this light, the Unterhaltungen may be regarded as a hybrid discourse of sorts, introducing scientific and philosophical questions of method and logic into an experimental literary form, and thereby yielding an unexpected discursive alloy.

Like Luise, who had protested at too quick a conceptual leap from the individual to the entire human species, Goethe believes that too bold and sweeping an attempt at synthesis is where great risk of error lies, and this is why he claims to be ill at ease when called on to 'theorize.' "Dagegen werden wir finden," he concludes in "Der Versuch als Vermittler," "daß diejenigen am meisten geleistet haben, welche nicht ablassen alle Seiten und Modifikationen einer einzigen Erfahrung, eines einzigen Versuches nach aller Möglichkeit durchzuforschen und durchzuarbeiten" (17). The careful observation of a specific fact can yield richer insight, he maintains, than the formulation of the most ambitious general theory - so long as it proceeds in a sufficiently polyfocal manner. It is a matter of observing phenomena with patience, and turning them attentively to different angles in order to discern the different facets of their meaning within the context they are part of. This, of course, was the essence of the Old Man's advice to Luise-and, implicitly, to the reader in search of the novella's 'concept': "Es kommt freilich vieles auf die Beobachter an, und was für eine Seite man den Sachen abzugewinnen weiß." Goethe's way of approaching the infinite is to approach the finite from every angle available, and this is what he does in the Unterhaltungen, giving each perspective its voice- even at the expense of narrative unity.

"Geschichtliches Dasein," writes Gerd Ueding, is in Goethe's view "verworrenes Dasein, ist Wirrwarr, Irrung, Finsternis, weil es keine klare, abgegrenzte Stufenfolge verschiedener Zustände und Begebenheiten gibt, die einander zwanglos ablösen, sondern ein dauernder Wirbel von Verschlingungen" 
(Ueding, 129). Hartmut Reinhardt similarly argues that Goethe had come, by the 1790s, to see the course of history as above all a matter of "Schicksal"a thing largely beyond our control, determined by chance more than by reason, and as such "unfaßbar in ihrer Dynamik von diskontinuierlichen Sprüngen und Rückschlägen" (Reinhardt, 311). Indeed, the Unterhaltungen, as an immediate product of the political and cultural climate of the mid-1790s, may be seen as a corrective to philosophical constructions of history that Goethe saw coming to prevalence at that time. Whereas a close associate such as Herder will posit broad narratives that span centuries of human experience, Goethe's own reflections on generalizable laws of continuity and development will be restricted largely to domains such as, say, plant metamorphosis, in which change can more easily be empirically observed, and putative laws more easily tested. In interpreting history, however, we do not have the same possibility to make first-hand observations and to systematically test hypotheses; to methodically observe and test broader arcs of human experience would require a higher vantage than what our perspective affords us, and this constraint forces us into speculation. Should our ideas venture too far beyond our capacity for empirical observation, though, our work risks becoming, Goethe suggests, increasingly a matter of imagination rather than of science. Whereas in "Der Versuch als Vermittler" Goethe had presented a set of Kautelen for the scientific interpreters of Naturphänomene, we may regard the Unterhaltungen as comprising conceptually analogous Kautelen for the philosophical interpreters of Weltbegebenheiten. The hypotheses, theories, terminologies, and systems that our intellects generate must not be fallaciously ascribed to history itself, Goethe cautions, because they may have more to do with our own intellectual constitution than with the actual nature of what we interpret.

In "Bedenken und Ergebung," a document from his later morphological work, Goethe comments on the persisting difficulty

daß zwischen Idee und Erfahrung eine gewisse Kluft befestigt scheint, die zu überschreiten unsere ganze Kraft sich vergeblich bemüht. Demohngeachtet bleibt unser ewiges Bestreben diesen Hiatus mit Vernunft, Verstand, Einbildungskraft, Glauben, Gefühl, Wahn und, wenn wir sonst nichts vermögen, mit Albernheit zu überwinden (Goethe, Werke, vol. 13, 31).

As the emigrés' conversations in the Unterhaltungen unfold, every one of these approaches-from reason to silliness—-seems to be in play. As Fritz's conjectures about the two desks show, the more we exercise our capacity for scientifically grounded conjecture, the more we find ourselves engaging the imagination as well, and indeed it is precisely at the point where explaining the broken desk calls the relationship between experience and explanation most directly into question that the narrative makes its leap into the unmitigated fantasy of the fairy tale. Mooting an idea for the novella's conclusion 
to Schiller, Goethe writes: "es würde vielleicht nicht übel sein, wenn [die Unterhaltungen] durch ein Produkt der Einbildungskraft gleichsam ins Unendliche ausliefen" (Goethe, Gedenkausgabe, 96), and, true to this intention, the concluding Märchen begins when Karl requests that Einbildungskraft be at last untethered from the constraints of Vernunft and Verstand. The Unterhaltungen had begun with the radical antinomy represented by Karl and the Privy Councillor, had progressed by dialogically seeking harmony among opposites, and now find their culmination in the bizarre alchemical attempt at overarching synthesis represented by the Märchen. Making a somewhat abrupt leap in the way it departs from the main narrative, this final tale delivers the conclusion of Goethe's experiment. With its exuberant play of ineffable symbolic images, it may indeed be seen as perfecting, in a certain sense, what the novella has progressively been working toward: the highest-perhaps infinite?-form of Unterhaltung. "[E]s unterhält mich," Goethe writes to Schiller, "und wird also doch wohl auch einigermaßen für andere unterhaltend sein" (100). "Unterhaltung" is of course conversation and diversion, but it is also, as the novella illustrates, necessity and sustenance, and, in the case of the Märchen, what appears for Goethe to be more a matter of diversion also works to fulfill, in the context of Schiller's project, a political and cultural necessity. The Old Man, introducing this final tale, enigmatically announces it as "ein Märchen, durch das Sie an nichts und an alles erinnert werden sollen" (Goethe, Werke, vol. 6, 209), and in this sense, too, it may represent a culmination of what the Unterhaltungen have sought to capture: overcoming the foregoing individualism and antagonisms, the fairy tale seems to say everything and nothing, to side with everyone and no one, and thereby to arrive as far as it imaginably can from the novella's fraught starting point. Though richly laden with symbols, little of that meaning lies on the surface for us to readily grasp. Yet while any intrinsic meaning is impossible to pin down, the well-crafted unity of a poem is at the same time palpably present. Unresolvable tensions seem at last to be resolved; this resolution occurs, nevertheless, in a realm other than reality.

Thus completing the arc from a bald "Kampf entgegengesetzter Meinungen und Parteien" to a fairy tale that symbolically transcends such politics, the Unterhaltungen deutscher Ausgewanderten answer-in a simultaneously earnest and ironic way-Schiller's call for "fröhliche Zerstreuung." The literary experiment that Goethe carries out is one that tests both the capacity of Schiller's ideals to be embodied in representational narrative, and, conversely, of the capacity of such narrative to rise to Schiller's conceptual challenges. The outcome of these experiments - and, we may infer, the result of any attempt to thoroughly synthesize the incongruous manifold of experienceis, for Goethe, a very vivid fairy tale. Like the Baroness, or Luise, or Fritz, we are, by our natures, compelled to look for unity, coherence, and reason in 
the things we perceive, even if the narratives we squeeze experience into may ultimately, as Goethe provocatively suggests, be just a diversion. In the Unterhaltungen, Goethe decidedly foregrounds the discontinuities and inconsistencies within narrative in order thereby to foreground the analogous discontinuities and inconsistencies of experience itself, and, in doing so, to show the problems of attempting to systematize it. Thus responding to the logically ordered narratives of history that had been gaining prominence since the Enlightenment, and seemingly critiquing — already before the fact- the more ambitious systematizations of history of philosophers from Hegel onward, Goethe produces a methodologically earnest jest that engages in contemporary dialogue about politics at the same time that it debunks it. Experience is fraught with chance, he believes, and, like fairy tales, discursive attempts to transcend its inconsistencies will only evade reality rather than capture it. Narrative strategies that foreground imperfection, meanwhile, have their own virtues, because those very imperfections-even the most maddeningly inscrutable ones-are the hallmarks of the reality we seek to grasp. "Sie sollten sich doch endlich diese Paradoxen abgewöhnen, die das Gespräch nur verwirren," exclaimed Luise in exasperation at the Old Man's perplexing way of talking. "[E]rklären Sie sich deutlicher! [... ] Hätten Sie sich eigentlicher ausgedrückt, so hätten wir nicht gestritten." "Aber auch nicht gesprochen," the Old Man replies. "Verwirrungen und Mißverständnisse sind die Quellen des tätigen Lebens und der Unterhaltung" (186).

${ }^{1}$ According to Tang, the relation of the particular to the general is not just central to Goethe's novella, but indeed, historically, to the genre itself. "The novella first came into being as a legal genre" in the Roman Empire, he writes, and it emerged "as a literary genre [...] at the height of the reception of Roman law in fourteenth-century Italy" (Tang, 67, 69). Common to both the legal and the literary iterations of the novella is "its function: it seeks to turn factual contingency into a stable normative order" (69); thus, "Boccaccio's literary novella resembles Justinian's legal novella in that both make a normative order out of the factual circumstances of singular cases" (71). Suggesting a deep consistency in Goethe's thought, this reading of the Unterhaltungen demonstrates the same core conceptual problem-relating singular instances to general laws-that one finds thematized in the work's philosophical and scientific intertexts.

${ }^{2}$ The most thorough exposition of this dialogue is in Gaier.

${ }^{3}$ The Old Man's remark adumbrates an epistemological problem further thematized in Goethe's later scientific writing: "in der Idee [ist] Simultanes und Sukzessives innigst verbunden, auf dem Standpunkt der Erfahrung hingegen immer getrennt, und eine Naturwirkung, die wir der Idee gemäß als simultan und sukzesssiv denken sollen, scheint uns in eine Art Wahnsinn zu versetzen" (Goethe, Werke, vol. 13, 31-32).

${ }^{4} \mathrm{On}$ the critique of Newton with regard to the Unterhaltungen, see Sullivan, $158 \mathrm{f}$.

${ }^{5}$ See, for example, the 1798 essay "Erfahrung und Wissenschaft": "Denn da der Beobachter nie das reine Phänomen mit Augen sieht, sondern vieles von seiner Geistesstimmung, von der Stimmung des Organs im Augenblick, von Licht, Luft, Witterung, Körpern, Behandlung und tausend andern Umständen abhängt; so ist ein Meer auszutrinken, wenn man sich an Individualität des Phänomens halten und diese beobachten, messen, wägen und beschreiben will" (Goethe, Werke, vol. 13, 24). 


\section{Works Cited}

Boyle, Nicholas. Goethe: The Poet and the Age, vol. 2: Revolution and Renunciation (17901803). Oxford: Clarendon, 2000.

Fricke, Gerhard. "Zu Sinn und Form von Goethes Unterhaltungen deutscher Ausgewanderten." Formenwandel (Festschrift for Paul Böckmann). Walter Müller-Seidel and Wolfgang Preisendanz, eds. Hamburg: Hoffmann und Campe, 1964: 273-293.

Gaier, Ulrich. "Soziale Bildung gegen ästhetische Erziehung: Goethes Rahmen der Unterhaltungen als satirische Anthithese zu Schillers Ästhetischen Briefen I-IX." Poetische Autonomie? Zur Wechselwirkung von Dichtung und Philosophie in der Epoche Goethes und Hölderlins. Helmut Bachmaier and Thomas Rentsch, eds. Stuttgart: Cotta, 1987: 207-272.

Goethe, Johann Wolfgang von. Gedenkausgabe der Werke, Briefe und Gespräche, vol. 20: Briefwechsel mit Friedrich Schiller. Ernst Beutler, ed. Zurich: Artemis, 1950.

Goethe, Johann Wolfgang. Sämtliche Werke I, vol. 9: Wilhelm Meisters theatralische Sendung, Unterhaltungen deutscher Ausgewanderten. Wilhelm Voßkamp and Herbert Jaumann, eds. Frankfurt am Main: Deutscher Klassiker Verlag, 1992.

Goethe, Johann Wolfgang von. Werke: Hamburger Ausgabe in 14 Bänden, vol. 6: Romane und Novellen I. Erich Trunz and Benno von Wiese, eds. Munich: Deutscher Taschenbuch Verlag, 1998.

Goethe, Johann Wolfgang von. Werke. (Hamburger Ausgabe in 14 Bänden.) Vol. 13: Naturwissenschaftliche Schriften I. Dorothea Kuhn und Rike Wankmüller, eds. Munich: Deutscher Taschenbuch Verlag, 1998.

Mommsen, Katharina. "Bilde, Künstler! Rede nicht! Goethes Botschaft an Schiller im Märchen." Theatrum Europaeum (Festschrift for Elida Maria Szarota). Richard Brinkmann et al., ed. Munich: Fink, 1982: 491-516.

Neumann, Gerhard. "Naturwissenschaft und Geschichte als Literatur: Zu Goethes kulturpoetischem Projekt." Modern Language Notes, vol. 114, no. 3, (April 1999): 471-502.

Pfaff, Peter. "Das Horen-Märchen: Eine Replik Goethes auf Schillers Briefe über ästhetische Erziehung." Geist und Zeichen (Festschrift for Arthur Henkel). Herbert Anton et al., eds. Hamburg: Winter, 1977: 320-332.

Reinhardt, Hartmut. “Ästhetische Geselligkeit: Goethes literarischer Dialog mit Schiller in den Unterhaltungen deutscher Ausgewanderten." Prägnanter Moment: Studien zur deutschen Literatur der Aufklärung und Klassik (Festschrift for Hans-Jürgen Schings). Peter-André Alt et al., eds. Würzburg: Königshausen und Neumann, 2002: 311-341.

Schiller, Friedrich. Schillers Werke, vol. 22: Vermischte Schriften. Herbert Meyer et al., eds. Weimar: Böhlau, 1958.

Sullivan, Heather. "Ecocriticism, Goethe's Optics, and Unterhaltungen deutscher Ausgewanderten: Emergent Forms Versus Newtonian 'Constructions.'” Monatshefte vol. 101, no. 2 (2009): 151169.

Tang, Chenxi. "The Transformation of the Law of Nations and the Reinvention of the Novella: Legal History and Literary Innovation from Boccaccio's Decameron to Goethe's Unterhaltungen deutscher Ausgewanderten." Goethe Yearbook 19 (2012): 67-92.

Ueding, Gerd. "Gesprächsgesellschaft in Utopia: Goethes Unterhaltungen deutscher Ausgewanderten." Aufklärung über Rhetorik: Versuche über Beredsamkeit, ihre Theorie und praktische Bewährung. Tübingen: Niemeyer, 1992: 125-137.

Witte, Bernd, "Das Opfer der Schlange: Zur Auseinandersetzung Goethes mit Schiller in den Unterhaltungen deutscher Ausgewanderten und im 'Märchen."' Unser Commercium: Goethes und Schillers Literaturpolitik. Wilfried Barner et al., eds. Stuttgart: Cotta, 1984: 461-484.

Michael Saman

301 Lakewood Drive

Asheville, NC 28803

USA

michaeljsaman@gmail.com 